
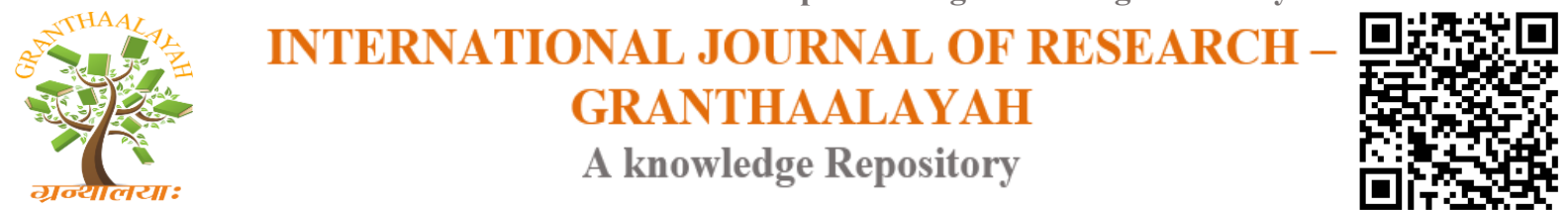

Science

\title{
BIOGAS PRODUCTION FROM CO-DIGESTION OF SELECTED AGRICULTURAL WASTES IN NIGERIA
}

\author{
Sambo, A. S. ${ }^{1}$, Etonihu, A. C. ${ }^{* 2}$, Mohammed, A. M. ${ }^{3}$ \\ ${ }^{1}$ Sokoto Energy Research Centre, Usmanu Danfodio University, Sokoto, NIGERIA \\ ${ }^{2}$ Chemistry Department, Nasarawa State University, PMB 1022, Keffi, NIGERIA \\ ${ }^{3}$ Department of Basic Science, College of Agriculture, PMB 33, Lafia, NIGERIA
}

\begin{abstract}
The fear of depletion of fossil fuels and their attendant ecological effects and the high cost of renewable energy technology in Nigeria has triggered a need to develop alternative sources of energy, among which is biogas production. A slurry of $1 \mathrm{~kg}$ mixture of agro-waste feed stocks (plantain peel/rice husk, PP/RH; banana peel/plantain peel, BP/PP; and banana peel/rice husk, $B P / R H)$ in 1:1 ratio was co-digested in locally fabricated digesters (10 L capacity). The experiment was run for 50 days and assessed for proximate content, biogas generation, organic matter, and mineral content in the digested and undi-gested agro-waste materials. The proximate composition showed that while banana peel had the highest moisture (56\%), rice husk was highest in the content of ash (64\%), crude protein (6.94\%), and volatile solids (20\%). The weekly cumulative biogas generation increased from $852.6 \mathrm{~cm} 3$ for BP/PP sample to 1049.7 cm3 for PP/RH sample for the 7 weeks at the experimental room temperature range of 29 oC to 35 oC. Sample PP/RH generated the highest volume of gas (biogas, methane, and others) compared to $\mathrm{BP} / \mathrm{RH}$ and $\mathrm{BP} / \mathrm{PP}$ samples. In each case the volume of gas production decreased in week 7 from $271.4 \mathrm{~cm} 3$ to $152.0 \mathrm{~cm} 3$ (for biogas), $161.4 \mathrm{~cm} 3$ to $97.1 \mathrm{~cm} 3$ (for methane), and $110.0 \mathrm{~cm} 3$ to $54.9 \mathrm{~cm} 3$ (for other gases). The nutritional concentrations of the digested and undigested mixture of the waste samples after Atomic Absorption Spectrophotometer (AAS) and Flame Photometry showed that the digested samples had higher contents of the nutritional elements than the undigested samples. The mineral elements ranged from $0.554 \mathrm{mg} / \mathrm{g}$ in the undigested rice husk to $18.155 \mathrm{mg} / \mathrm{g}$ in the digested banana peel samples. Fermentation of agricultural wastes to generate biogas and sludge with agricultural value offers an al-ternative and efficient method of agricultural wastes and energy management in Nigeria.
\end{abstract}

Keywords:

Agro-waste, biogas; energy crisis, methane.

Cite This Article: Sambo, A. S., Etonihu, A. C. and Mohammed, A. M., "BIOGAS PRODUCTION FROM CO-DIGESTION OF SELECTED AGRICULTURAL WASTES IN NIGERIA" International Journal of Research - Granthaalayah, Vol. 3, No. 11(2015): 7-16. 


\section{INTRODUCTION}

Over the centuries man has searched various sources of energy in order to meet his basic energy requirements. These include energy from electricity, nuclear, water, wind, the sun in the forms of fuel wood, coal and petroleum, to mention a few. Currently fossil fuel is leading and provides the world source of primary energy [1].

Despite the fear of depletion of fossil fuels and their attendant ecological effects [2], the high cost of renewable energy technology in Nigeria has triggered a need to develop alternative sources of energy, among which is biogas production. The gases methane, hydrogen, and carbon monoxide (CO) can be combusted or oxidized with oxygen. The energy released allows biogas to be used as a fuel for heating purposes such as cooking. Biogas can be compressed, much like natural gas, and used to power motor vehicles [3]. In the UK, for example, biogas is estimated to have the potential to replace around $17 \%$ of vehicle fuel [3]. Biogas can also be cleaned and upgraded to natural gas standards when it becomes biomethane [3]. Although biogas technology is not common in Nigeria, various research works on the science, technology and policy aspects of biogas production has been carried out by various scientists in the country. Similarly, some significant research has been done on reactor design by some Nigerian scientists that would lead to process optimisation in the development of anaerobic digesters [4-6].

It has been estimated that Nigeria generates $20 \mathrm{~kg}$ of municipal solid waste per capita annually [7], and which has continued to increase with increasing population [8]. Biogas technology has played and will continue to play a role in waste management [9]. Biogas production may therefore be a profitable means of reducing or even eliminating the menace and nuisance of urban wastes in many cities in Nigeria [10]. Plantain, banana and rice constitute major food crops in Nigeria. As a result, large quantities of wastes are often generated from the peels and husks. Indiscriminate disposal of these wastes and their concomitant decomposition often produce noxious gases such as hydrogen sulphide, ammonia etc., which pose serious environmental hazards. Channeling these peels and husks into the production of biogas could serve as an efficient way for the management of the wastes, while the resulting biogas could serve as a source of energy for cooking and lighting for the populace. Biogas production and the resultant residue with enhanced plant nutrients are known to have the following advantages:

I. Abundant and readily available resources (agricultural wastes) that find no industrial application can be used in biogas generation.

II. The use of agricultural wastes in energy generation offers a major control strategy against environmental pollution and sanitation.

III. Desertification of the environment through the use of fire wood as domestic source of energy and other forms of energy crisis can be greatly minimized.

It is important to note that biogas is generated when biomass and other waste decaying and decomposing matter are digested by bacteria. The four key biochemical stages of anaerobic digestion in biogas production are hydrolysis, acidogenesis, acetogenesis, and methanogenesis [11 - 13]. Hydrolysis of the high-molecular-weight polymeric biomass is the necessary first step in anaerobic digestion [11-13]. Through hydrolysis the complex organic molecules are broken down into simple sugars, amino acids, and fatty acids. Acetate and hydrogen produced in the first stages 
can be used directly by methanogens. Other molecules, such as volatile fatty acids (VFAs) with a chain length greater than that of acetate must first be catabolized into compounds that can be directly used by methanogens [11 - 13]. The biological process of acidogenesis results in further breakdown of the remaining components by acidogenic (fermentative) bacteria [11 - 13]. The third stage of anaerobic digestion (acetogenesis), simple molecules created through the acidogenesis phase are further digested by acetogens to produce largely acetic acid, as well as carbon dioxide and hydrogen [11 - 13]. The terminal stage of anaerobic digestion is methanogenesis, whereby methanogens use the intermediate products of the preceding stages and convert them into methane, carbon dioxide, and water. These components make up the majority of the biogas emitted from the system. Methanogenesis is sensitive to both high and low $\mathrm{pH}$ and occurs between $\mathrm{pH} 6.5$ and $\mathrm{pH}$ $8[14,15]$.

A simplified generic chemical equation for the overall processes outlined above is as follows:

$$
\begin{aligned}
& \mathrm{C}_{12} \mathrm{H}_{22} \mathrm{O}_{11}+\mathrm{H}_{2} \mathrm{O} \longrightarrow \quad 2 \mathrm{C}_{6} \mathrm{H}_{12} \mathrm{O}_{6} \quad \ldots 1 \\
& \mathrm{C}_{6} \mathrm{H}_{12} \mathrm{O}_{6} \longrightarrow \quad 3 \mathrm{CO}_{2}+3 \mathrm{CH}_{4} \quad \ldots 2
\end{aligned}
$$

The aim of this study is to search for an alternative source of clean energy through environmental protection and capacity building by waste-to-energy conversion for wealth creation. This work involves generation of biogas from plantain, banana and rice-husk wastes from a locally fabricated digester, assessment of the biogas for methane, organic matter and moisture content, and determination of the mineral content $(\mathrm{K}, \mathrm{Na}, \mathrm{Ca}, \mathrm{Mg}, \mathrm{P}$ and $\mathrm{N})$ in the digested and undigested agro-waste materials. The concentrations of these nutrients in the digested and undigested samples were compared to ascertain the best sludge with the highest bio-fertilizer potential.

\section{MATERIALS AND METHODS}

\subsection{SAMPLES COLLECTION AND PRE-TREATMENT}

Plantain and banana peels were collected in large quantities from bulk purchasing outlets in Lafia metropolis, Nasarawa State, Nigeria; while $2.5 \mathrm{~kg}$ of rice husk was obtained from a rice producing community in Kilema, eastern part of Lafia, and was pulverized using mortar and pestle. The samples were separately homogenized using an electric blender and thereafter allowed to undergo an initial fermentation in a plastic container (20 L capacity), and agitated with a corning agitator for five days.

\subsection{FABRICATION OF THE BIOGAS DIGESTERS (REACTORS)}

Three laboratory type anaerobic digesters (10 L capacity), labeled A, B and C were fabricated at the Federal University of Agriculture, Makurdi, Nigeria. The digester was made of cast iron (30 $\mathrm{cm}$ in diameter and $60 \mathrm{~cm}$ high) with gas holder, slurry/sample inlet, gas outlet, and beam (Fig. 1). The gas produced (methane) was collected by the downward displacement of water. The operation of the digester was carried out at room temperature following the method of AOAC [16]. 


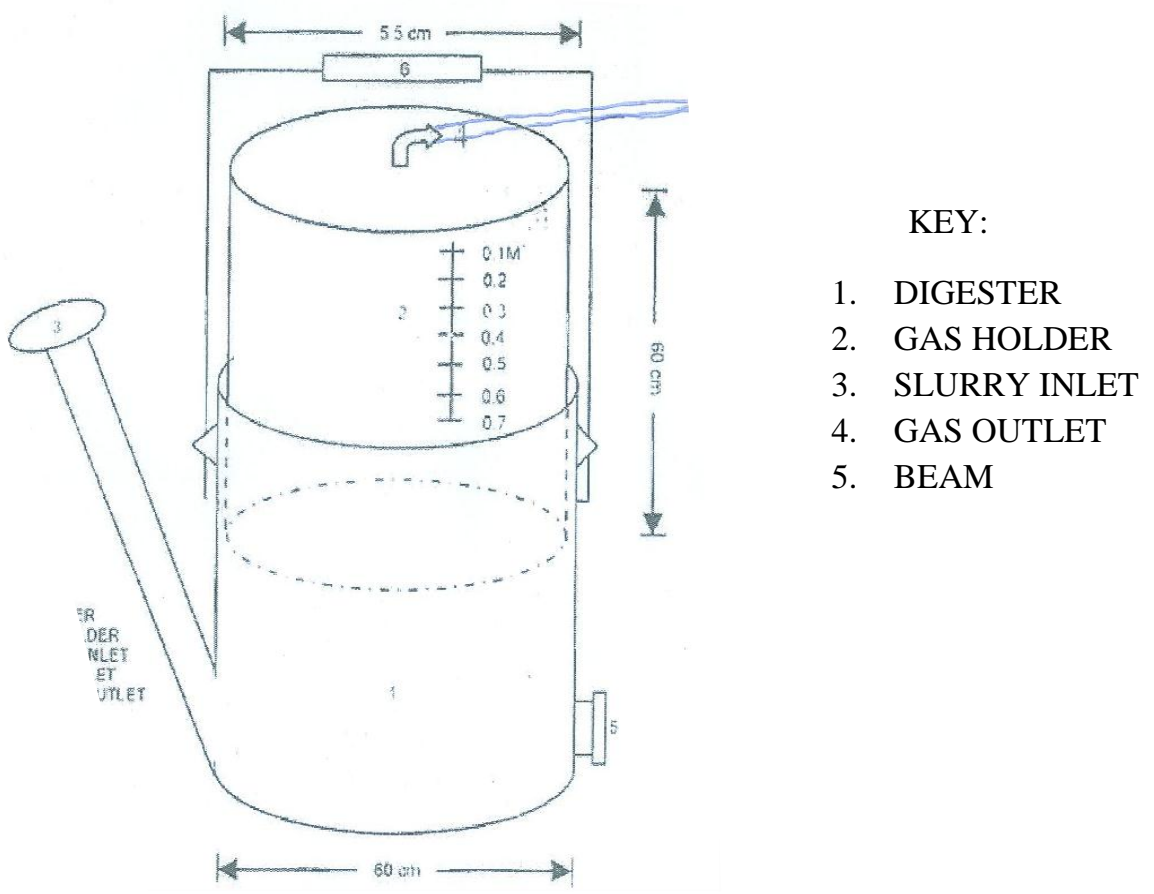

Figure 1: Fabricated Biogas Digester

\subsection{PREPARATION OF THE FEEDSTOCK}

The digesters were operated using $1 \mathrm{~kg}$ mixture of the different feed stocks in 1:1 ratio (banana peels, plantain peels and rice husks). Digester A contained banana peels and rice husks; Digester $\mathrm{B}$ contained banana and plantain peels; Digester $\mathrm{C}$ contained rice husk powder and plantain peels. These feedstock formulations were mixed thoroughly in separate containers with $2.5 \mathrm{~L}$ of distilled water before transferring into the digesters. The digesters were allowed to run for 50 days during which the volume of gas produced (methane) was recorded daily. The entire experiment was repeated in duplicate for reproducibility.

\subsection{PROXIMATE ANALYSIS}

Moisture and ash contents were determined using the standard procedures of AOAC [16], while organic matter content was calculated by difference. Crude nitrogen was determined in both the digested and undigested samples by the Kjeldahl method. The nitrogen content of the sample was calculated using the formula:

$$
\mathrm{N}=\frac{\mathrm{T} \times \mathrm{M} \times 0.014 \times \mathrm{V} 1 \times 100}{\mathrm{~g} \times \mathrm{V} 2}
$$

Where $\mathrm{T}=$ titre value of $\mathrm{HCl}, \mathrm{M}=$ concentration of $\mathrm{HCl}=0.01 \mathrm{M}$

$\mathrm{V} 1=$ volume of water used for dilution of digest, $\mathrm{g}=$ weight of sample in $\mathrm{g}$ $\mathrm{V} 2=$ volume of the aliquot used $=20 \mathrm{~cm}^{3}$ 


\subsection{MINERAL ANALYSIS OF THE DIGESTED AND UNDIGESTED SLURRY}

Determinations of $\mathrm{K}, \mathrm{Na}, \mathrm{Mg}, \mathrm{Ca}$, and $\mathrm{P}$ were carried out in accordance with standard AOAC methods [16]. $\mathrm{Mg}$ and $\mathrm{Ca}$ were determined using Atomic Absorption Spectrophotometer (AAS model 969 UNICAN), while K, Na and $\mathrm{P}$ were determined using flame photometer (corning 400). Calibration curves were prepared for each determination by plotting galvanometer deflections against concentration of the standards. The amount of each ion present per gramme of sample in the extract was calculated from the standard curves.

\section{RESULTS AND DISCUSSIONS}

\subsection{PROXIMATE COMPOSITION OF THE AGRO-WASTE SAMPLES \\ $+$}

The proximate composition showed that while banana peel had the highest moisture (56\%), rice husk was highest in the content of ash, crude protein, and volatile solids (Table 1). The higher crude protein content $(6.94 \%)$ in the rice husk samples may be associated with nitrogenous chemical fertilizer application of rice farm lands. During anaerobic digestion, microorganisms act on organic matter component of the plants to produce biogas [17].

Table 1: Percent Proximate Composition of the Solid Waste Samples

\begin{tabular}{lcccc}
\hline Samples & Moisture & Ash & Crude Protein & Volatile Solid \\
\hline BP & 56 & 30 & 5.12 & 14 \\
PP & 32 & 58 & 3.97 & 10 \\
RH & 16 & 64 & 6.94 & 20
\end{tabular}

$\mathrm{BP}=$ Banana Peel; $\mathrm{PP}=$ Plantain Peel; RH $=$ Rice Husk; \% Crude protein $=\% \mathrm{~N} \times 6.25$

This indicated that the relative moisture, ash and volatile solids in a given plant materials will influence the amount of biogas production. High quantities of moisture and ash will result in low organic matter content and consequently low biogas yield, on the other hand low moisture and ash content will result in high organic matter content and therefore high biogas yield. Combination of banana/ plantain peels gave lower amount of gas probably because of the lower organic matter. While plantain peels/ rice husk gave the highest volume of gas. BP/RH combination could have yielded more gas than PP/RH combination, but high inorganic content and other possible factors suppressed its gas production [17].

\subsection{GENERATION OF BIOGAS, METHANE AND OTHER GASES}

Table 2 showed that weekly cumulative biogas generation increased from $852.6 \mathrm{~cm}^{3}$ for BP/PP sample to $1049.7 \mathrm{~cm}^{3}$ for PP/RH sample for the 7 weeks at the experimental room temperature range. Generally the volumes of gas obtained were low, and increased with the period of the experiment. This increase may be as a result of increasing fermentation rate leading to proportional increase in volume as the days progressed. These results are comparable with those obtained by Eze [18]. Furthermore, Table 3 showed that sample PP/RH generated the highest volume of gas 
(biogas, methane, and others) compared to BP/RH and BP/PP samples. In each case the volume of gas production decreased in week 7 from $271.4 \mathrm{~cm}^{3}$ to $152.0 \mathrm{~cm}^{3}$ (for biogas), $161.4 \mathrm{~cm}^{3}$ to 97.1 $\mathrm{cm}^{3}$ (for methane), and $110.0 \mathrm{~cm}^{3}$ to $54.9 \mathrm{~cm}^{3}$ (for other gases). This decrease in gas production may be due to depletion in the amount of substrate as the reaction progressed with the number of weeks traversed.

Total methane production for the period under study showed that PP/RH generated the highest volume of methane compared with $\mathrm{BP} / \mathrm{RH}$ and BP/PP (Table 3). Ilori et al. [19] investigated production of biogas from co-digestion of banana and plantain peels using a $10 \mathrm{~L}$ laboratory scale anaerobic digester. The highest volume of biogas was obtained when the banana and plantain peels were in equal proportions as feedstock.

Table 2: Weekly and Cumulative Biogas Generation $\left(\mathrm{cm}^{3}\right)$ at 29 to $35{ }^{\circ} \mathrm{C}$

\begin{tabular}{lcccrrr}
\hline $\begin{array}{l}\text { No. of } \\
\text { Weeks }\end{array}$ & BP/PP & $\begin{array}{c}\text { Weekly } \\
\text { SAMPLES } \\
\text { BP/RH }\end{array}$ & PP/RH & BP/PP & \multicolumn{3}{c}{$\begin{array}{c}\text { Cumulative } \\
\text { SAMPLES } \\
\text { BP/RH }\end{array}$} \\
\hline 1 & 29.9 & 31.3 & 39.7 & 29.9 & 31.3 & 39.7 \\
2 & 55.2 & 60.0 & 71.0 & 85.1 & 91.3 & 110.7 \\
3 & 98.7 & 105.1 & 118.4 & 183.8 & 196.4 & 229.1 \\
4 & 144.8 & 155.9 & 170.6 & 328.6 & 352.3 & 399.7 \\
5 & 191.3 & 209.2 & 226.6 & 519.9 & 561.5 & 626.3 \\
6 & 227.3 & 250.3 & 271.4 & 747.1 & 811.8 & 897.7 \\
7 & 105.5 & 113.1 & 152.0 & 852.6 & 924.9 & 1049.7
\end{tabular}

$\mathrm{BP}=$ Banana Peel; PP = Plantain Peel; RH = Rice Husk

Table 3: Weekly Production of Biogas, Methane and other Gases $\left(\mathrm{cm}^{3}\right)$

\begin{tabular}{llllllllll}
\hline \multirow{2}{*}{$\begin{array}{l}\text { No. of } \\
\text { Wks }\end{array}$} & \multicolumn{3}{c}{ Vol. of Biogas } & \multicolumn{3}{c}{ Vol. of Methane } & \multicolumn{3}{c}{ Vol. of Other gases } \\
& BP/PP & BP/RH PP/RH & BP/PP & BP/RH & PP/RH & BP/PP & BP/RH & PP/RH \\
\hline 1 & 29.9 & 31.3 & 39.7 & 19.2 & 20.5 & 24.3 & 10.7 & 10.8 & 15.4 \\
2 & 52.2 & 60.0 & 71.0 & 29.8 & 36.3 & 42.0 & 22.4 & 23.7 & 29.0 \\
3 & 98.7 & 105.1 & 118.4 & 50.0 & 55.4 & 60.6 & 48.7 & 49.7 & 57.8 \\
4 & 144.8 & 155.9 & 170.6 & 70.7 & 77.1 & 83.9 & 74.1 & 78.8 & 86.7 \\
5 & 191.3 & 209.2 & 226.6 & 112.0 & 121.8 & 134.0 & 79.3 & 87.4 & 92.6 \\
6 & 227.3 & 250.3 & 271.4 & 139.1 & 156.5 & 161.4 & 88.2 & 93.8 & 110.0 \\
7 & 105.5 & 113.1 & 152.0 & 62.2 & 66.7 & 97.1 & 43.3 & 46.4 & 54.9 \\
\hline \multicolumn{2}{l}{ BP/PP = Banana Peel/Plantain Peel; BP/RH } \\
\hline
\end{tabular}

Seeding of co-digested pig waste and cassava with wood ash was reported to result into significant increase in biogas production compared with unseeded mixture of pig waste and cassava peels [20]. Odeyemi [21] compared Eupatorium odoratum, water lettuce, water hyacinth and cow dung as potential substrates for biogas production. Eupatorium odoratum gave the highest yield of 
biogas, while cow dung was the poorest substrate. He concluded that E. odoratum was a cheap source of biogas in Nigeria because of its luxuriant and ubiquitous growth. Optimization of biogas yield through co-digestion of organic wastes using rice husks has been reported by several researchers. For instance, Eze [18] reported that the addition of poultry droppings to rice husk at an average temperature of $29.4^{\circ} \mathrm{C}$ resulted to cumulative biogas yield of $39.70 \mathrm{l} / \mathrm{g}$.TS up from $18.37 \mathrm{l} / \mathrm{g}$.TS, gas yield obtained from rice husk alone at the same conditions and within 18 days retention period was high. Sahota and Rajinder [22] also reported that the addition of rice husk soaked in water at $20 \%$ level in a cattle dung digester increased biogas production. Uzodinma et al. [23] reported that blends of rice husk with brewer's spent grain and cassava waste water with carbonated soft drink sludge increased biogas yield of between 240 to $250 \mathrm{~m}^{3}$ respectively, while also reducing significantly the time taken for gas flammability to set in. Similarly, when rice husk was co-digested with cow dung in a ratio of 1:1 and 1:4 there was an observed increase in biogas yield different from that of the rice husk alone. This increased biogas yield was attributed to the cow dung, with the rice husk contributing nothing to the biogas production [24]. Methanogenesis is the final stage of the biogas process. In this stage, methane and carbon dioxide (biogas) are formed by various methane-producing microorganisms called methanogens. The most important substrates for these organisms are hydrogen gas, carbon dioxide, and acetate, which are formed during anaerobic oxidation [25]. But other substrates such as methyl amines, some alcohols, and formates can also be used for the production of methane [25]. Just like in other stages of the biogas process, not just one, but several different types of microorganisms are active in this stage. The methane-producing group that usually dominates in a biogas process is the so-called acetotrophic methanogens, which use acetate as substrate. In their metabolism, acetate is cleaved into two parts. One of the carbons is used to form methane and the other to form carbon dioxide. Thus, acetotrophic methane producers are sometimes also called acetate-splitting methanogens. Acetate is the source of about $70 \%$ of the biogas produced in a digestion tank [26].

\subsection{BIO-FERTILIZER POTENTIAL OF UNDIGESTED/DIGESTED MANURE}

Table 4 provided the nutritional concentrations of the digested and undigested mixture of the waste samples after AAS and Flame Photometry.

Table 4: Nutritional Concentration of the waste samples (mg/g)

\begin{tabular}{lrrrrrrrrrrrr}
\hline & \multicolumn{9}{c}{ Undigested } & \multicolumn{1}{c}{ Digested } \\
Samples & $\mathrm{K}$ & $\mathrm{Na}$ & $\mathrm{Mg}$ & $\mathrm{Ca}$ & $\mathrm{N}$ & $\mathrm{P}$ & $\mathrm{K}$ & $\mathrm{Na}$ & $\mathrm{Mg}$ & $\mathrm{Ca}$ & $\mathrm{N}$ & $\mathrm{P}$ \\
\hline $\mathrm{BP}$ & 0.89 & 1.21 & 1.59 & 1.92 & 1.61 & 0.58 & 9.56 & 13.66 & 16.44 & 18.16 & 1.97 & 1.59 \\
$\mathrm{PP}$ & 1.21 & 1.66 & 1.26 & 1.51 & 1.25 & 0.11 & 15.62 & 14.55 & 14.63 & 13.22 & 1.97 & 2.66 \\
$\mathrm{RH}$ & 0.65 & 0.55 & 1.25 & 1.10 & 1.16 & 0.61 & 3.25 & 3.14 & 12.61 & 14.62 & 1.05 & 3.11 \\
& & & & & & & & & & & &
\end{tabular}

BP = Banana Peel; PP = Plantain Peel; RH = Rice Husk

The results showed that the digested samples have higher contents of the nutritional elements than the undigested samples. The mineral elements ranged from $0.554 \mathrm{mg} / \mathrm{g}$ in the undigested rice husk to $18.155 \mathrm{mg} / \mathrm{g}$ in the digested banana peel samples. The importance of $\mathrm{K}, \mathrm{Na}, \mathrm{Mg}, \mathrm{Ca}, \mathrm{N}$, and $\mathrm{P}$ to plants cannot be over emphasized as they are relevant for photosynthesis and metabolism, root 
formation, growth, flowering, and seed formation [27, 28]. A comparison of the concentrations of these nutrients in the digested and undigested samples can be an indicator to ascertain the best sludge with the highest bio-fertilizer potential. This shows that although these are considered to be waste samples, they still contain appreciable nutritional values. And further explains why these agro-wastes find usefulness in animal feed formulations. Digester manure is the product of biogas fermentation consisting of sludge and effluent. The sludge contains most of the primary nutrient elements and organic matters. The nutrients are elements contained in the digested manure and are different depending on the substrate [29]. All microorganisms require very dilute salt concentration to function. The salts contain essential building blocks such as sodium, potassium, magnesium etc, for the microorganisms. These substances are available in many substrates and do not need to be added to the biogas process separately. However, high salt concentrations will inhibit the microorganisms in the biogas process. Salts (and sugars) generally have a preservative effect; they inhibit bacterial growth by causing the cell to dehydrate and lose both form and function [29].

\section{CONCLUSIONS}

It could be concluded from the foregoing that:

I. Fermentation of agricultural wastes to generate biogas and sludge with agricultural value offers an alternative and efficient method of controlling agricultural wastes decomposition in the environment.

II. Enhanced food production can be achieved by using established slurry from biogas generation as fertilizer instead of dependency on the chemical fertilizer.

III. Amongst the three agricultural wastes tested for biogas potentiality, combination of plantain peel/rice husk showed optimum biogas generation.

\section{REFERENCES}

[1] Asere, AA. and Aliyu, UO. Outlook of Nigeria's energy predicament. Nigerian Journal of Renew able Energy3, (1992, 92-95.

[2] American Society of Agricultural Engineers.Manure Production and Characteristics. ASAE Standards 1996, $44^{\text {th }}$ Ed.The Society for Engineering in Agricultural, Food and Biological System, 1997.

[3] Sweeten, JM. Animal Waste Management: Task Force Report. New York, 2004, 10 -12.

[4] Adeoti, O. Engineering economy studies of biogas as a renewable energy source at household level in Nigeria. Unpublished M.Sc. thesis in Technology Planning and Development Unit, Faculty of Technology, Obafemi Awolowo University, Ile -Ife, Nigeria, 1998.

[5] Igoni, AH, Ayotamuno, MJ., Ogaji, SOT. and Probert, SD. Municipal solid waste in Port Harcourt, Nigeria J.of Applied Energy, El 84 (6), 2008, 664 -670.

[6] Ezekoye, VA. and Okeke, CE. Design, Construction, and Performance evaluation of plastic biodigester and the Storage of Biogas. Pacific Journal of Science and Technology 7(2), 2006, 176-184.

[7] Matthew, P. Gas production from animal wastes and its prospect in Nigeria. Nigerian Journal of Solar Energy, 2, 1982, 98-103. 
[8] Akinbami, JFK. Comparative environmental effects and cost Analysis between conventional and non-conventional energy source: A case for objective analysis and decision making in Nigeria's energy policy. Nigerian Journal of Renewable Energy5 (1 \&2), 1997, 131-139.

[9] Themelis, NJ. An Overview of the Global Waste-to-Energy Industry. Waste Management World, 2003, 40-47.

[10] Akinbami, JFK., Ilori MO., Oyebisi, TO., Akinwuni, IO. and Adeoti, O. Biogas energy use in Nigeria: current status, future prospects and policy implications. Renewable and Sustainable Energy Reviews 5, 2001, 97-112.

[11] Kalia, VC., Sonakya, V. and Raizada, N. Anaerobic digestion of banana stems waste. J. Bioresource Technol., 73, 2000, 191-193.

[12] Kozo, I., Hisajima, S. and Macer, DRJ. Utilization of Agricultural Wastes for biogas production in Indonesia, In: Traditional technology for environmental conservation and sustainable development in the Asia Pacific region. Proceedings of the UNESCO,1 $1^{\text {th }}-14^{\text {th }}$ Dec, 1996, $134-138$ a

[13] Ofoefule, AU., Uzodinma, EO. and Onukwuli, OD. Comparative study of the effect of different pretreatment methods on biogas yield from water hyacinth (Eichhornia Crassipes). Int. J. Phy. Sci. 4(8), 2009, 535-539.

[14] Arvanitoyannis, IS., Kassaveti, A. and Stefanatos, S. Current and potential uses of thermally treated olive oil waste. Int. J. Food Sci. Tech. 42 (7), 2007, 852-867.

[15] Bori, M.O., Adebusoye, S.A., Lawal, A.K and Awotiwon, A. Production of biogas from banana and plantain peels. Journal ofAdvances in Environmental Biology 1(1), 2007, 33 -38 .

[16] Association of Official Analytical Chemists (AOAC). Official Methods of Analysis. Washington DC, USA, 1990.

[17] Svensson, K., Odlare, $M$. and Pell, M. The fertilizing effect of compost and biogas residues from source separated household waste. J. Agricultural Science.142, 2004, 461 - 467.

[18] Eze, JI. (Unpublished). Studies on Generation of Biogas From Poultry Droppings and Rice Husk from a Locally Fabricated Biodigester. M.Sc. Dissertation, University of Nigeria, Nsukka, 1995, 64-65.

[19] Ilori, SA., Matthew, O., Adebusoye, AK. and Oluwatoyin AA. Production of biogas from banana and plantain peels, Am-Eurasian J. Sustain. Agric., 1 (1), 2007, 33-38.

[20] Odeyemi, S. Resource assessment for biogas production in Nigeria. Nigerian J. Microbiol. 3, 1983, 59-64.

[21] Adeyanju, AA. Effect of seeding of wood-ash on biogas production using pig waste and cassava peels. J. Eng. Appl. Sci.3, 2008, 242-245.

[22] Sahota, P. and Rajinder, KJ. Biogas yield from cow and rice husks wastes.J. Plant Sci. Res. 1, 1997, 13.

[23] Uzodinma, EO., Ofoefule, AU, Eze, JI. and Onwuka, ND. Biogas Production from blends of Agro-industrial wastes. Trends in Appl. Sci. Res., 2(6), 2007, 554 -558.

[24] Iyagba, ET., Mangibo, IA. and Mohammed, YS. The study of cow dung as a co-substrate with rice husk in biogas production. J. Scientific Research and Essays4(9), 2009, 861-866.

[25] Liu, Y. and Whitman, WB. Metabolic, phylogenetic, and ecological diversity of the methanogenic archaea.Annual New York Academy of Sciences 1125, 2008, 171-189. 
[26] Zindler, SH. Physiological ecology of methanogenesis.Methanogenesi: Ecology, Physiology, Biochemistry and Genetics (Ferry, J.G., ed.). New York, Chapman and Hall, 1993, $128-206$.

[27] Rivard, CJ., Rodriquez, JB., Nagel, NJ., Self, JR., Kay, BD., Soltanpour, PN. and Nieves, $R A$. Anaerobic digestion of municipal solid waste. Utility of processresidue as a soil amendment. Applied Biochemistry and Biotechnology 51-52, 1995, 125-135.

[28] Odlare, M., Pell, M. and Svensson, K. Changes in soil chemical andmicrobiological properties during 4 years of application of various organic residues. Waste Management 28, 2008, 1246-1253

[29] Baky, A., Nordberg, A., Palm, O., Rhode, L. and Salomon, E. (2006). Rötrester från biogasanläggningar-användning i lantbruket. JTI report 115. Engl. Transl. 